from about the year Iooo until the end of the I 4 th century. The ultimate fate of the Norse settlers in Greenland is shrouded in mystery, as there is no authentic record of their existence after the end of the fourteenth century. There has also in later days been great diversity of opinion where to seek for the settlements; thus the Danish explorer Graah, who, in the years I828-3r, searched for remains of the same, sought them west of Cape Farewell, but without success. Baron Nordenskjöld is, however, of the opinion that the Österbygd and the Norse settlements were situated east of the Cape, and it is here that he intends to search for them. It is hardly necessary to enlarge on the interesting and important results to science which would accrue from the discovery of these "dead cities" on the shores of the Arctic Ocean. Baron Nordenskjöld will start on his journey early in May next, and although the general expenses of the expedition, no doubt, will be defrayed by King Oscar and Dr. Oscar Dickson, it is the intention of the latter to apply to the Swedish Parliament for the use of one of the vessels of the Navy for the voyage.

MORE details have now reached us concerning the expedition of the African travellers, Lieut. Wissmann and Pogge. The travellers proceeded along the Kassai River diring the autumn of $188 \mathrm{r}$, passed through Kimbunda and reached Kidimba, the residence of Chingenge, the chief of the Tooshilange tribe, in November. Then they proceeded northwards. They reached the frontier of the West African savannah-forests and entered upon the densely populated prairies of Central Africa. In the middle of December they reached the Mukamba Lake. Now they traversed the well-populated country of the Bashilange and reached the Lubi, a magnificent river bordered by rich tropical vegetation, and which is a tributary of the Lubilash river. The opposite shore of the Lubi is inhabited by the Bassonge, a handsome and powerful tribe, which possesses numerous clean and cheerful villages adorned by palm and banana trees. On January 14, 1882, the travellers reached the capital on the left bank of the Lubilash, in $5^{\circ} 7^{\prime} 18^{\prime \prime}$ lat. S. Kachich, the chief of the Kotto district, whose power is based upon his reputation of fetishero (high priest), caused many obstacles to be thrown into their way. At last, on January 29, the expedition crossed the Lubilash, which is identical with the Sankura, and which flows into the Congo. This was in $5^{\circ} 13^{\prime}$ lat. S. Then they passed through well-watered prairies, inhabited by the warlike Bassonges, by the Beneckis, who have villages 17 kilometres in length, and the Kalebues, reaching and crossing the Lomami River on March 8. All these tribes are cannibals. Between the Lubi and Lake Tanganyika, Wissmann found remains of what must once have been the natives of these parts, viz. the Batuas, little, undergrown, slender, dirty, and savage-looking people, who live only by the chase and on wild fruit, speak a curious language, and whose arms and implements indicate a very low state of civilisation. The Lomami was crossed in $5^{\circ} 42^{\frac{1^{\prime}}{2}}$ lat. S. The direction towards Nyangwe was now taken through flooded prairies and marshes, alternating with parts where the grass had grown to a perfect carpet resembling felt. The Lufubu River was crossed on April 2. By April in two canoes had been made. On April 16 the expedition reached the Lualaba River, and Nyangwe on the 17 th, where they were well received by the Arabs. Here they resolved to separate. Pogge was to return to the Mukenge Station with the caravan, and Wissmann to the east. On May 5 Pogge left. Wissman started on June I with only a few companion:, and eventually reached Cassongo and then Lake Tanganyika. At Manyema he had gone south of Stanley's and Cameron's route, and afterwards crossed it at $\mathrm{Ca}=$ Bambarre, passing northward into the land of the WasiMalungo and Ubngwe tribes towards Uguhla. On the shores of Lake Tanganyika Wissmann rested for fourteen days, staying at the missionary station of Ruande. He made an excursion to the Lukuga River and crossed the lake to Ujiji. On August 9 he left the caravan track, proceeding in a northerly direction to Uhha, to visit the renowned chief, Mirambo. Passing through many great dangers he reached Mirambo's residence, and was most hospitably received. On September 3 Wissmann reached the French mission-station at Tabora, from whence he made an excursion to the German African Society's station at Gonza. There he considered his geographical work as completed, inasmuch as Dr. Kaiser had proceeded to Gonza from the east coast. Wissmann found Dr. Boehm and Reichard both in good health, Dr. Kaiser having left a few days before. On November I8 Wissmann reached the east coast near Saadani.
IT is announced by the hon. secretaries of the Egyptian Exploration Fund that Sir Erasmus Wilson, LL.D., F.R.S., has accepted the office of President of the Society, and has headed the subscription list with a donation of 50ol. Thus launched, the Society has commenced excavations at Tel-eIMaskhuta, in the Wady 'Iumilat-this mound being the supposed site of Raamses, one of the two cities specified in the first chapter of Exodus as built by the forced labour of the Hebrews. M. Edouard Naville, the eminent Swiss Egyptologist, in cooperation with Prof. Maspero, has undertaken the direction of the excavation on this important site, where he is now at work, aided by an experienced engineer, and a gang of eighty labourers. The results to be anticipated from discoveries at Tel-el-Maskhuta are inscriptions which shall enable Egyptologists to identify the Pharaoh of Moses, to assign a dynastic date to the period of the oppression, and to settle the much-disputed question regarding the route of the Exodus. More, funds are needed for the prosecution of the work already begun, and it is hoped that the public will liberally support the action of Sir Erasmus Wilson. Pending the election of a treasurer, subscriptions will be received by the hon. secretaries, Mr. Reginald Stuart Poole, British Museum, and Miss Amelia.B. Edwards, the Larches, Westburyon-Trym, Bristol.

In the March number of Petermann's Mittheilungen the principal paper is an account of Herr Fr. von Schenck's journey in the United States of Columbia in I880, an important contribution to the physical geography of a country on which we have no very recent information. Dr. Capus gives some interesting information on the valley of Yagnan and its inhabitants, about 170 versts east of Samarcand. There is a brief sketch of Herr Schuver's journey to the sources of the Tumat, Jabus, and Jal, in the region lying between the Upper Bahr-el-Azrek and Bahr-el-Abiad. This number contains the Necrology for $\mathbf{1 8 8 2 .}$ -In Nos. IO, II, and $\mathrm{I} 2$ (in one) Band xxv. of the Mittheilungen of the Vienna Geographical Society is a paper, with map, by Dr. J. Morstadt on the mountain structure of South Tyrol. An important work in ten vols. on the peoples of Austria-Hungary, by many authors (Vienna, Prochaska), is reviewed by Dr. Paulitschke.-Nearly the whole of the Compte Rendu of the Paris Geographical Society for December I5 is occupied by M. Desiré Charnay's account of his explorations in Yucatan.

\section{ON THE PRESENT CONDITION OF THE SODA} INDUSTRY

$A \mathrm{~N}$ interesting and important paper with the above title was read by Mr. Walter Weldon, F.R.S., at a meeting of the Society of Chemical Industry held at Burlington House on January 8. The following abstract is condensed from this paper as published in the Fournal of the Society:-

A few years ago there were twenty-five alkali-works in the neighbourhood of Newcastle-on-Tyne; now there are only thirteen. Seven or eight works are standing idle in Lancashire; in Belgium the manufacture of soda by the Leblanc process has entirely ceased. The following table represents the

\section{Present Soda Production of the World in tons}

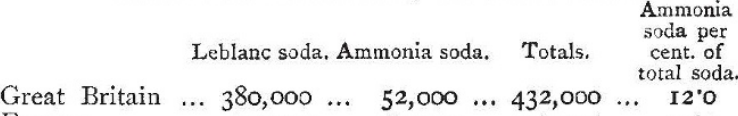

$\begin{array}{lllllllllll}\text { France } & \ldots & \ldots & 70,000 & \ldots & 57,125 & \ldots & 127,125 & \ldots & 44^{\circ} 9\end{array}$

$\begin{array}{lllllllllll}\text { Germany } & \ldots & \ldots & 56,500 & \ldots & 44,000 & \ldots & 100,500 & \ldots & 43 \cdot 8\end{array}$

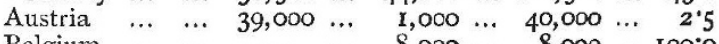

$\begin{array}{lllllllllll}\text { Belgium } & \ldots & \ldots & - & - & \ldots & 8,000 & \ldots & 8,000 & \ldots & 100^{\circ}\end{array}$

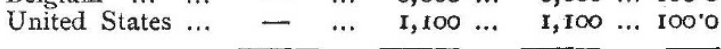

$$
\text { Totals } \ldots \overline{545,500} \quad \overline{163,225} \quad \overline{708,725} \quad \overline{23} \cdot 0
$$

The ammonia process for making soda dates, as a practical manufacturing method, from 1866, in which year M. Solvay of Brus:els established works at Couillet, near Charleroi. M. Solvay is now manufacturing soda by the ammonia process at the rate of about 75,000 tons per annum.

The production of soda has very rapidly increased on the Continent within the last five years; the greater part, but not the whole, of this increase is due to the introduction of the ammonia process. The production of soda by this process in England is entirely in the hands of one firm-Messrs. Brunner and Mond: in 1875 this firm produced 2500 tons of soda, in 
1880 they produced 18,800 tons, and their output is now at the rate of 52,000 tons per annum. The new works now in course of construction in this country and on the Continent, when completed, will at once increase the production of ammonia soda by 65,000 to 70,000 tons annually.

What then can the manufacturer of Leblanc soda expect save utter collapse? But the state of the alkali-maker threatens to become even worse than it is. The source of the sulphur which is used in the Leblanc process is pyrites; the pyrites employed in this country is almost exclusively imported by three large companies from Spain and Portugal; it contains from 2 to 3 per cent. of copper, and very small quantities of silver and gold. When the soda manufacturer has burnt off the sulphur, he sends the residual ore to the -copper extractor, who is able to sell the iron oxide which remains when he has taken out the copper at about 12s. per ton. Now the French soda-manufacturers make use of pyrites of their own, which contains little or no copper ; one of the large companies which supplies the English market purposes, therefore, to start works in France, which shall eaploy Spanish pyrites, but which shall depend for their profits, not on the soda which they manufacture, but on the copper and $i$ on oxides remaining after the sulphur has been burnt off from the pyrites. This company, which starts with a capital of over a million sterling, speaks of building five large works in France, and one in the neighbourhood of Antwerp.

The Leblanc soda manufacturers have tried to persuade themselves that the price of ammonia must rise considerably, and that thus they may be able to compete with the ammonia sodamakers on more equal terms than at present. But in place of ammonia becoming dearer, its price is steadily falling. New sources of ammonia are being found; a process for collecting ammonia and other volatile products from coke-ovens, which is easily applied to existing ovens, has recently been patented by Mr. J. Jameson of Newcastle-on-Tyne. If this method should be generally applied to the coke-ovens in this country, a quantity of ammonia corresponding to 180,000 tons of ammonium sulphate, worth about three and a half millions sterling, would be annually saved.

Mr. Ferrie-a member of the great iron firm of William Baird and Co.--has also contrived a method whereby the ammonia and tarry matters which are present in the gases of the blast furnace may be condensed ; this process has been at work for some time at Gartsherrie, and by its help about 20 lbs. of ammonium sulphate are obtained per ton of coal burnt in the blast furnaces.

Another difficulty which presses heavily on the manufacturer of soda by the Leblanc process consists in the want of an ou let for the great quantities of hydrochloric acid which accumulate during the soda manufacture.

This difficulty is not felt by the Continental manufacturer because he finds a rearly market for the chlorine which can be extracted from hydrochloric acid ; but in England the supply of chlorine at present much exceeds the demand. But Mr. Weldon holds out hopes to the English chlorine-maker; he says : "I think that our English manufacturers of Leblanc soda will have to cease to devote their hydrochloric acid-when they do not throw it away-exclusively to chlorine making; . . . the difficulty hitherto has been how to turn it to account otherwise. I believe that difficulty is about to disappear. I am not free to enter into that matter now ; . . . but I have very great confidence that new applications of hydrochloric acid, admitting of being applied very exten ively, at comparatively small expense, are among the things of the immediate future."

Mr. Weldon then considers the ways in which the English manufacturer of Leblanc soda may hope to recover himself and agai 1 make soda at a reasonable profit. First of all, be must get his pyrites about 50 per cent. cheaper than the price he now pays for it; the present combination between the pyrites companies will expire at the end of next year; after that time the price of pyrites must, in $\mathrm{Mr}$. Weldon's opinion, fall very considerably.

Secondly, the soda-manufacturer must recover all the sulphur in his alkali waste; if he can recover the sulphur at a cost not exceeding 21 . per ton, he will become master of the sulphur market, as the actual cost of Sicilian sulphur delivered at Marseilles is now about $5 l$. per ton.

The third thing which the soda-manufacturer must do is to distil the coal which he now uses as fuel, condense and sell the volatile products, including tar, oils, and ammonia, and employ the residual coke as fuel; he will thus get his fuel for nothing, and at the same time will ccnfer an inestimable boon on the towns where coal is now largely used as fuel.

These three courses, says Mr. Weldon, must be all adopted by the English soda-maker. If, in addition to doing this, the strictest economy in manufacture is practised and the purest and best product that can be made is always turned out, the manufacturer of soda by the old Leblanc method may yet hope to hold his own against the new and wonderfully successful ammonia process.

M. M. P. M

\section{UNIVERSITY AND EDUCATIONAL INTELLIGENCE}

OXFORD. - The following persons have been elected Members of the Committee for the nomination of examiners in the Natural Science Schoo!s : Prof. R. B. Clifton; Prof. W. Odling; and Proí. H. N. Moseley. The Vice Chancellor and Proctors com. plete the Committee. Up till this term the nomination of examiners lay with the Vice-Chancellor and Proctors, who appointed in turn.

The Examiners for the Burdett Coutts Geological Scholarship have recommended Mr. F. W. Andrews, of Christ Church, for election.

Magdalen College advertises a demyship in Natural Science to be competed for in June.

CAMBRIDGE.-The following further appointments of Boards of Electors to Professorships have been made:-

Mineralogy :-Prof. Story-Maskelyne (Oxford), Dr. H. C. Sorby, Profs. Stokes, Warrington Smyth, and Liveing, Dr. Phear, Dr. Percy, and Mr. Glazebrook.

Mental Philosophy and Logic:-Prof. Crnom Robertson (Univ. Coll. Lond.), J. B. Mayor (King's Coll. Lond.), and Adamson (Owens College), Messrs. H. Sidgwick, I. Ward, I. Todhunter, Shadworth H. Hodgson, and the Master of Trinity College.

Music:-Sir F. Ouseley, Messrs, Pole, T, P. Hudson, G. Grove, Sedley Taylor, G. F. Cobb, R. Pendlebury, and E. S. Thompson.

Mr. Albert Schafer, F.R.S., Fullerian Professor of Physiology at the Royal Institution, has been appointed Jodrell Professor of Physiology at University College, London, in the vacancy occasioned by the resignation of Dr. J. Burdon Sanderson, LL.D., F.R.S., appointed Wayneflete Professor of Physiology in the University of Oxford.

\section{SOCIETIES AND ACADEMIES LONDON}

Chemical Society, February I.-Dr. Gilbert, president, in the chair.-The following were elected Foreign Members :F. Beilstein, P. T. Cléve, H. Debray, E. Erlenmeyer, R. Fittig, H. Helmholtz, D. Mendeleeff, Victor Meyer, Lothar Meyer. The following were elected ordinary Fellows : $-H$. C. Bond, G. C. Basu, J. Brock, A. M. Chance, J. T. Donald, H. C. Foote, W. Fox, W. R. Flett, J. A. M. Fallon, E. C. Gill, F. Gothard, J. Hunter, H. Jones, B. R. Lee, A. H. Jackson, Joowansinghi, T. Jenner, J. E. Johnson, W. W. J. Nicol, F. W. Richardson, E. S. Spencer, C. A. Serré, T. Turner, J. E. Tuit.-The following papers were read:-On derivatives of fluorene, by W. R. E. Hodgkinson and F. E. Matthews. The fluorene was crystallised five or six times from alcohol; it melted at $113^{\circ}$; when pure, it does not fluoresce. A dibrom and monobrom derivative were obtained, and a fluorene sulphonic acid; by the action of caustic potash on the potassium sulphonate, a trihydroxy-diphenyl was formed; and by dropping the hydro. carbon into fused caustic potash, a dihydroxy-diphenyl was procured.-On the action of chlorine on certain metals, by $R$. Cowper. As observed by Wanklyn, dry chlorine has no action upon melted sodium; the author finds that dry chlorine has no action upon Dutch metal, zinc, or magnesium; it acts very slowly upon silver and bismuth; tin, arsenic, and antimony are attacked rapidly, with evolution of heat.-Some notes on hydrated ferric oxide, and its behaviour with sulphuretted bydro. gen, by L. T. Wright. The author found great difficulty in obtaining ferric hydrate, by precipitating the chloride with am. monia, free from basic chloride. Having poured some ferric chloride into an excess of ammonia, he evaporated to dryness at $100^{\circ}$. The residue, when treated with water, gave a reddish solution which would not yield a clear filtrate, some of the 